\title{
Associations between job demands, perceptions of noise at work and the psychological contract
}

\author{
Mohamad Irwan Ahmad ${ }^{12}$ and Andrew P Smith ${ }^{1}$, \\ ${ }^{1}$ Centre for Occupational and Health Psychology, School of Psychology, \\ Cardiff University, 63 Park Place, Cardiff CF10 3AS, \\ ${ }^{2}$ Deceased \\ smithap@cardiff.ac.uk
}

\begin{abstract}
Despite the widespread interest in the effects of workload on behaviour, there has been little research on the effects of it on attitudes and values in the workplace and life generally. The aim of the present research was to examine associations between noise exposure (which increases workload) and components of the psychological contract (fairness; trust; organisational commitment; work satisfaction; motivation; organisational citizenship; and intention to stay/quit). 166 workers completed a survey measuring components of the psychological contract, perceptions of noise exposure and other job characteristics. Univariate analyses showed that higher noise exposure was associated with a more negative psychological contract. However, adjustment for other job characteristics, both negative (e.g. job demands) and positive (e.g. control and support), removed the significant effects of noise. These results confirm previous research suggesting that psychosocial stressors have greater behavioural effects than components of the physical working environment such as noise.
\end{abstract}

Keywords: psychological contract; noise; job demands; wellbeing

\section{Introduction}

\subsection{Mental Workload}

There has recently been renewed interest in models and applications of mental workload [1, 2, 3]. Mental workload has been investigated in many different ways [4, 5], and it has a long history in Experimental and Applied Psychology [6, 7]. It has been examined in laboratory studies [8,9] and in the workplace [10, 11], and a variety of measures of workload have been put forward [12, 13, 14, 15, 16, 17]. These include subjective reports, measures of task parameters and physiological function. Self-assessment or subjective reports such as the NASA Task Load Index [18], the Workload Profile [19] and the Subjective Workload Assessment Technique [4] have been widely used. Even single items about perceptions of mental workload are now used, and these are often highly correlated with longer scales and can predict wellbeing and other outcomes. Other research has examined specific aspects of 
workload, such as time pressure, and this approach formed the basis of the Karasek Job Demands scale, which has been found to predict safety and health outcomes of workers [20].

\subsection{Effects of Noise on Performance}

One explanation of the negative effects of noise on performance is that the noise acts as an extra source of information that requires extra resources. These resources are then no longer available for the task being performed and performance is impaired $[21,22]$. This view is supported by studies which have measured workload and shown that it is increased in noise [23, 24, 25, 26, 27]. In addition, the extra workload may lead to increased stress and, in the long term, chronic health problems. There has been little research on the effects of noise on attitudes and values in the workplace and life generally.. The present study examined the Psychological Contract which is the exchange relationship between the organization and employee.

\subsection{The Psychological contract}

In the Psychological Contract the employee gives an obligation to the organization, and, in return, the organization will respond with some terms and agreement [28]. The Psychological Contract is seen as playing an important role in explaining changes in relationships between employees and their organization [29, 30, 31]. A 'Psychological Contract Breach' happens when employees feel that the organization does not support their well-being but is only safeguarding the interests of the organization. The employee might not be prepared to face change but may be required to deliver their best without rewards that are commensurate with the difficulties caused by the change. As a result, their well-being at the work place is disturbed and eventually could lead to various performance-related effects such as low work performance [32, 33], low engagement [34] and weak organizational citizenship behavior [35, 36, 37]. Both parties may suffer negative consequences with the organization no longer operating effectively and employees no longer having an interest in their work. When a breach of the Psychological Contract occurs, employees may exhibit negative emotional stress like anger, disappointment and betrayal and, finally, they may cease to work efficiently and may intend to quit the organization [38]. The model proposed by Guest [39] showed the attitudinal and behavioral effects related to changes in the Psychological Contract. In this model the background factors were both individual and organizational characteristics. When the Psychological Contract was working well this led to a state of "Fairness", "Trust" and "The delivery of the deal". Attitudinal consequences of the Psychological Contract include: organizational commitment, work satisfaction, good employment relations, good work-life balance and job security. The behavioral consequences include: high motivation/effort, organizational citizenship and intention to stay in the job rather than quit. Work effort can be defined as the amount of energy employees put in to work successfully [40]. Work effort is different from motivation and there is always some confusion between both of these definitions. In this case, motivation comes first and is the psychological state that pushes the employees to make an effort of any required behaviors [41]. 


\subsection{Aims and Objectives}

The aim of the present study was to examine whether the perception of noise at work (a risk factor for increased workload) influenced Psychological Contract Fulfilment (perceptions of fairness, trust and fair treatment). Organizational commitment was the key attitudinal consequence measured. Affective commitment was another variable measured here and it refers to the emotional attachment between the employee and the organization. Effort and intention to quit were the behavioral consequences investigated. One could suggest that wellbeing outcomes should also have been examined. Recent research [42, 43, 44] has shown that changes in wellbeing attributed to the Psychological Contract can be better explained by other job characteristics or individual characteristics. Indeed, this is a common issue in occupational workload research, where effects attributed to workload turn out to be due to correlated attributes. For example, some of the effects of noise on accidents reflect the fact that job with high noise levels also involved dangerous machinery [45]. Negative job characteristics were, therefore, also measured, as were positive job characteristics which could plausibly account for high Psychological Contract Scores.

\section{Method}

This study was carried out with the approval of the ethics committee, School of Psychology, Cardiff University and the informed consent of the volunteers.

\subsection{The Survey}

An online survey was carried out using Qualtrics software.

\subsection{Measuring Instruments}

In the present study fairness, trust, delivery of deals and overall Psychological Contract Fulfilment were measured using The Psychological Contract Fulfilment Scale developed by Guest and Conway [28]. The measurement assessed the extent to which the respondent felt the organization had kept its promises ( 7 items), treated them fairly ( 2 items) and how much they trusted the organization (4 items). Example items include "Has the organization fulfilled its promise or commitment to.... provide you with a reasonably secure job", "Overall, do you feel you are fairly rewarded for the amount of effort you put into your job." and "To what extent do you trust your immediate manager to look after your best interests."

A main focus of the study was on the attitudinal and behavioural consequences of Psychological Contract Fulfilment. Affective organizational commitment was measured using the Affective, Normative and Continuance Commitment Scale [46]. In the present study, the Work Effort Scale developed by De Cooman et al. [47] was used. This scale consists of 10 -items which measure three dimensions of work effort, namely intensity, direction and persistence. These dimensions were summed to give an overall work effort score. In this study, intention to quit/ leave was measured using the scale developed by Kuvaas [48]. This scale contains 5-items and asks general questions about intention to leave the current job. 


\subsection{Participants}

The participants were 166 workers from the USA recruited using Mechanical Turk. Details of their demographics characteristics are shown in Table 1.

Table 1: Respondents' Demographic Profile

\begin{tabular}{|c|c|c|c|}
\hline Variable & $\begin{array}{l}\text { Response } \\
\text { Category }\end{array}$ & Frequency & $\begin{array}{c}\text { Percentage } \\
(\%)\end{array}$ \\
\hline \multirow{5}{*}{ Age } & 20-30 years & 54 & 32.5 \\
\hline & $31-40$ years & 68 & 41.0 \\
\hline & $41-50$ years & 21 & 12.7 \\
\hline & $51-60$ years & 11 & 6.6 \\
\hline & $61-70$ years & 12 & 7.2 \\
\hline \multirow[t]{2}{*}{ Sex } & Male & 96 & 57.8 \\
\hline & Female & 70 & 42.2 \\
\hline \multirow[t]{6}{*}{ Marital status } & Single & 59 & 35.5 \\
\hline & $\begin{array}{l}\text { Living with } \\
\text { partner }\end{array}$ & 29 & 17.5 \\
\hline & Married & 67 & 40.4 \\
\hline & Separated & 3 & 1.8 \\
\hline & Divorced & 7 & 4.3 \\
\hline & Widowed & 1 & 0.6 \\
\hline \multirow[t]{4}{*}{ Education } & Undergraduate & 108 & 65.1 \\
\hline & Post-Graduate & 51 & 30.7 \\
\hline & Doctorate & 4 & 2.4 \\
\hline & Other & 3 & 1.8 \\
\hline \multirow[t]{2}{*}{ Work sector } & Public & 68 & 41.0 \\
\hline & Private & 98 & 59.0 \\
\hline \multirow{2}{*}{$\begin{array}{l}\text { Full or part- } \\
\text { time work }\end{array}$} & Full time & 151 & 91.0 \\
\hline & Part-time & 15 & 9.0 \\
\hline \multirow[t]{3}{*}{ Work pattern } & Fixed hours & 116 & 69.9 \\
\hline & Flexi hours & 37 & 22.3 \\
\hline & Shift work & 13 & 7.8 \\
\hline
\end{tabular}




\section{RESULTS}

Perceived noise exposure was dichotomised into those who were never exposed to noise at work and those who were. The descriptive statistics for the dependent variables are shown for these groups in Table 2.

Table 2: Descriptive statistics for the Psychological Contract measures

\begin{tabular}{llccc}
\hline Variable & $\begin{array}{l}\text { Noise } \\
\text { Group }\end{array}$ & Mean & $\begin{array}{c}\text { Std. } \\
\text { Deviation }\end{array}$ & N \\
\hline \multirow{2}{*}{ Promises } & No Noise & 20.83 & 5.41 & 103 \\
& Noise & 17.56 & 5.44 & 63 \\
Fairness & No Noise & 13.56 & 3.10 & 103 \\
& Noise & 12.46 & 3.06 & 63 \\
Trust & No Noise & 20.94 & 4.47 & 103 \\
& Noise & 18.86 & 4.86 & 63 \\
Psychological & No Noise & 55.33 & 11.47 & 103 \\
Contract & Noise & 48.87 & 11.97 & 63 \\
Global & & & & \\
& & & & \\
Affective & No Noise & 27.73 & 5.68 & 103 \\
Commitment & Noise & 25.92 & 5.71 & 63 \\
& & & & \\
Work Effort & No Noise & 59.81 & 7.40 & 103 \\
& Noise & 57.40 & 10.03 & 63 \\
Intention to & No Noise & 11.36 & 5.30 & 103 \\
Quit & Noise & 14.22 & 6.00 & 63 \\
\hline
\end{tabular}

The group means show that those exposed to noise reported lower scores for promises, fairness, trust and the global Psychological Contract measure. In addition, they reported lower affective commitment, lower effort and a greater intention to quit the job. A MANOVA showed that the overall effect of noise was statistically significant (Wilks Lambda $=0.909 \mathrm{p}<0.05$ ) and individual ANOVAs showed that this was true for all the individual variables.

The next analysis examined whether this effect of noise remained significant when positive and negative job characteristics were included as covariates in the analyses. The factor scores for positive and negative job characteristics were included in these analyses. Positive job characteristics had an overall significant effect (Wilks Lambda $=0.605 \mathrm{p}<0.001)$ and also a significant effect for all the individual variables. The 
same was true for negative job characteristics (Wilks Lambda $=0.713 p<0.001$ ). The overall effect of perceived noise exposure was no longer significant in this analysis (Wilks Lambda $=0.976 \mathrm{p}=0.70$ ). There were no significant effects of noise in the analysis of the individual variables.

\section{Discussion}

The aim of this research was to examine the association between perceived exposure to noise at work, which may represent increased mental workload, and values, attitudes and behaviors that are part of the Psychological Contract. Perceived noise was assessed by a single question that examined the frequency of exposure to background noise at work that interferes with concentration on the job. Aspects of the Psychological Contract were measured using well established scales. An important feature of the research was the measurement of other job characteristics that have been shown to be associated with Psychological Contract measures [42, 43, 44] and with reported noise exposure [49].

\subsection{Effects of Noise}

The initial analyses suggested that exposure to noise at work led to a more negative attitude that influenced promises, perceived fairness and trust. Attitudinal consequences of this weaker Psychological Contract were also apparent as shown by the lower affective commitment scores. Behavioral consequences, as shown by reduced effort and a greater intention to quit, were also significant.

\subsection{Controlling for Job Characteristics}

The second set of analyses included positive and negative job characteristics. These had significant effects on the Psychological Contract variables, both overall and at the individual variable level. In addition, the effects of noise were no longer significant when these other job characteristics were included in the analyses.

Overall, the results of the present study show that initial consideration of noise in isolation suggests a negative impact on all parts of the Psychological Contract. However, adjustment for other job characteristics shows that it is these, not noise, that influence the strength of the Psychological Contract. In this respect, this is another study showing that it is the nature of the work carried out in noise, rather than noise per se, that influences attitudes and behavior. Mental workload, in the form of job demands, had a negative effect on the Psychological Contract and this effect accounted for the smaller effects of another source of mental workload, namely exposure to background noise.

\subsection{Limitations}

There are clear limitations associated with the present study. First, noise exposure would ideally be objectively measured. Secondly, workload should also be measured, preferably objectively but at the very least with subjective scales. It should be noted, 
however, that objective measures are difficult with online survey methodology. Thirdly, it is important to know the tasks that are carried out in noise as this often determines whether impairments are observed or not. Finally, a longitudinal design, preferably with an intervention, would be much better than the cross-sectional analyses presented here.

\section{Conclusion}

There has been little previous research on the effects of mental workload on attitudes and values. The Psychological Contract is the exchange relationship between the organization and employee where the employee offers an obligation to the organization and the organization in return will appreciate this with positive terms and agreements. The objective of the present research was to examine associations between noise exposure (which increases workload) and aspects of the Psychological Contract: trust; fairness; organizational commitment; job satisfaction; organizational citizenship; motivation and effort; and intention to stay/quit. Workers from a variety of jobs completed a survey measuring components of the psychological contract, perceptions of noise exposure and other job characteristics (e.g. job demands, control and support). Univariate analyses showed that higher noise exposure was associated with a more negative psychological contract. However, adjustment for other job characteristics, both positive and negative, removed the significant effects of noise. These results confirm previous research suggesting that psychosocial stressors have greater behavioral effects than components of the physical stressors such as noise.

\section{References}

1. Longo, L., Leva M.C. (eds.) Human Mental Workload: Models and Applications. H-WORKLOAD 2017. Communications in Computer and Information Science, vol. 726, pp. 251-263. Springer, Cham. (2017)

2. Longo, L., Leva, M.C. (eds.) Human Mental Workload: Models and Applications. H-WORKLOAD 2018. Communications in Computer and Information Science. Springer, Cham. (2019).

3. Longo, L., Leva, M.C. (eds.) Human Mental Workload: Models and Applications. H-WORKLOAD 2019. Communications in Computer and Information Science. Springer, Cham. (2019).

4. Reid, G.B., Nygren, T.E.: The Subjective Workload Assessment Technique: A Scaling Procedure for Measuring Mental Workload, vol. 52. NorthHolland (1988)

5. Stassen, H.G., Johannsen, G., Moray, N.: Internal representation, internal model, human performance model and mental workload. Automatica 26(4), 811--820 (1990)

6. De Waard, D.: The measurement of drivers' mental workload. The Traffic Research Centre VSC, University of Groningen (1996)

7. Hart, S.G.: Nasa-task load index (nasa-tlx); 20 years later. In: Human Factors and Ergonomics Society Annual Meeting. vol. 50. Sage Journals (2006) 
8. Smith, A.P., Smith, K.: Effects of workload and time of day on performance and mood. In: Megaw, E. D. (ed.) Contemporary Ergonomics, pp. 497--502. Taylor \& Francis, London (1988)

9. Evans, M.S., Harborne, D., Smith, A.P.: Developing an objective indicator of fatigue: An alternative mobile version of the Psychomotor Vigilance Task (m-PVT). Presented at: H-WORKLOAD 2018: International Symposium on Human Mental Workload: Models and Applications, Amsterdam, The Netherlands, 20-21 September 2018. Longo, L., Leva, M.C. (eds.): HWORKLOAD 2018, CCIS 1012, pp. 147--159, 2019. Springer Nature Switzerland. (2019)

10. Smith, A.P., Smith, H.N.: Workload, fatigue and performance in the rail industry. In: Longo, L., Leva M.C. (eds.) Human Mental Workload: Models and Applications. H-WORKLOAD 2017. Communications in Computer and Information Science, vol. 726, pp. 251-263. Springer, Cham. (2017)

11. Fan, J., Smith, A.P.: Mental workload and other causes of different types of fatigue in rail staff. In: Longo, L., Leva, M.C. (eds.) Human Mental Workload: Models and Applications. H-WORKLOAD 2018. Communications in Computer and Information Science 1012, pp. 147--159. Springer, Cham. (2019).

12. Cortes Torres, C.C., Sampei, K., Sato, M., Raskar, R., Miki, N. : Workload Assessment with Eye Movement Monitoring Aided by Non-invasive and Unobtrusive Micro-fabricated Optical Sensors. Adjunct Proceedings of the 28th Annual ACM Symposium on User Interface Software \& Technology pp. 53--54 (2015).

13. Yoshida, Y., Ohwada, H., Mizoguchi, F., Iwasaki, H.: Classifying Cognitive Load and Driving Situation with Machine Learning. Int. J. Mach. Learn. Comput. 4(3), 210--215 (2014)

14. Wilson, G.F., Eggemeier, T.F.: Mental workload measurement. In: Karwowski, W. (ed.) International Encyclopedia of Ergonomics and Human Factors (2nd ed.), vol. 1, chap. 167. Taylor \& Francis (2006)

15. Young, M.S., Stanton, N.A.: Mental workload. In: Stanton, N.A., Hedge, A., Brookhuis, K., Salas, E., Hendrick, H.W. (eds.) Handbook of Human Factors and Ergonomics Methods, chap. 39, pp. 1--9. CRC Press (2004)

16. Young, M.S., Stanton,N.A.: Mental workload: Theory, measurement, and applica- tion. In: Karwowski, W. (ed.) International Encyclopedia of Ergonomics and Human Factors, vol. 1, pp. 818--821. Taylor \& Francis, 2nd ed. (2006)

17. Moustafa, K., Saturnino, L., Longo, L.: Assessment of mental workload: a comparison of machine learning methods and subjective assessment techniques. In: 2017 1st International Symposium on Human Mental Workload: models and applications. vol. CCIS 726, pp. 30--50. Springer International Publishing (June 2017)

18. Hart, S.G., Staveland, L.E.: Development of NASA-TLX (Task Load Index): Results of Empirical and Theoretical Research. Adv. Psychol. 52(C), 139-183 (1988)

19. Tsang, P.S., Velazquez, V.L.: Diagnosticity and multidimensional subjective work- load ratings. Ergonomics. 39(3), 358--381 (1996) 
20. Karasek Jr, R.A.: Job demands, job decision latitude, and mental strain: Implications for job redesign. Adm. Sci. Q. 285-308 (1979).

21. Smith, A.P.: A review of the effects of noise on human performance. Scandinavian Journal of Psychology, 30, 185 - 206 (1989)

22. Smith, A. P., Jones, D. M.: Noise and performance. In: Handbook of human performance, Vol.1: The physical environment. (eds) A. P. Smith \& D. M. Jones. London: Academic Press. Pp.1-28 (1992)

23. McNeer, R., Bennett, C., Dudaryk, R.: Intraoperative noise increases perceived task load and fatigue in anesthesiology residents: A simulation based study. Anesth Analg, 122(2), 512-525 (2016)

24. Rosen, M., Dietz, A., Lee, N., Wang, I-J., Markowitz, J., Wyskiel, M. et al.: Sensor-based measurement of critical care nursing workload: Unobtrusive measures of nursing activity complement traditional task and patient level indicators of workload to predict perceived exertion. Plos One, 13(10), e0204819 (2018)

25. Jahncke, H., Bjorkeholm, P., Marsh, J., Odelius, J., Sorqvist, P.: Office noise: Can headphones and masking sound attenuate distraction by background speech? Work, 55(3), 505-513 (2016)

26. Gao, J., Liu, S., Feng, Q., Zhang, X., Zhang, J., Jiang, M. et al.: Quantitative evaluations of the effects of noise on mental workloads based on pupil dilation during laparoscopic surgery. Am Surg, 84 (12), 1951-1956 (2018)

27. Becker, A., Warm, J., Dember, W., Hancock, P.: Effects of jet engine noise and performance feedback on perceived workload in a monitoring task. Int $J$ Aviat Psychol, 5 (1), 49-62 (1995)

28. Rousseau, D. M.: Psychological and implied contract in organisations. Employee Responsibilities and Rights Journal, 2(2), 121-139 (1989)

29. Rousseau, D. M.: Psychological contract in organisations: Understanding written and unwritten agreements. Thousand Oaks, CA: Sage (1995)

30. Guest, D., Conway, R.: Communicating the psychological contract: An employer perspective. Human Resource Management Journal, 12(2), 22-38 (2002)

31. Dabos, G.E., Rousseau, D.M.: Mutuality and reciprocity in the psychological contract of employees and employers. Journal of Applied Psychology, 89(1), 52-72 (2004)

32. Marks, A.: Developing a multiple foci conceptualization of the psychological contract. Employee Relations, 23(5), 454 - 469 (2001)

33. Millward, L.J., Hopkins, L.J.: Psychological contracts, organizational and job commitment. Journal of Applied Social Psychology, 28(16), 1530-56 (1998)

34. Bal, M.P., De Cooman, R., Mol, T.S.: Dynamics of psychological contracts with work engagement and turnover intention: The influence of organizational tenure. European Journal of Work and Organisational Psychology, 22(1), 107-122 (2003)

35. Zhao, H., Wayne, S.J., Glibkowski, B.C., Bravo, J.: The impact of psychological contract breach on work-related outcomes: A meta-analysis. Personnel Psychology, 60(3), 647-680 (2007) 
36. Lee, K., Allen, N.J.: Organizational citizenship behavior and workplace deviance: The role of affect and cognitions. Journal of Applied Psychology, 87(1), 131-142 (2002)

37. Turnley,W.H., Bolino, M.C., Lester, S.W., Bloodgood, J.M.: The impact of psychological contract fulfilment on the performance of in-role and organizational citizenship behaviors. Journal of Management, 29(2), 187206 (2003)

38. Robinson, S. L., Kraatz, M., Rousseau, D.M. : Changing obligations and the psychological contract: A longitudinal study. Academy of Management Journal, 37(1), 137-152 (1994)

39. Guest, D. E.: Is the psychological contract worth taking seriously? Journal of Organisational Behaviour, 19(1), 649-664 (1989)

40. Ilgen, D. R., Klein, H.J.: Organizational behavior. In M.R. Rosenzweig \& L.W. Porter (Eds.), Annual Review of Psychology, 40, 327-51 (1989)

41. Bandura, A., Cervone, D.: Differential engagement of self-reactive influences in cognitive motivation. Organizational Behavior and Human Decision Processes, 38(1), 92-113 (1986)

42. Ahmad M.I., Firman, K., Smith, H., Smith, A.P.: Short Measures Of Organisational Commitment, Citizenship Behaviour And Other Employee Attitudes And Behaviours: Associations With Well-Being, BMIJ, 6(3): 516$550(2018)$

43. Ahmad, M.I., Firman, K., Smith, H., Smith, A. P.: Psychological Contract Fulfilment and Well-Being. Advances in Social Sciences Research Journal, 5(12) 90-101 (2018)

44. Smith, A.P., Smith, H.N.: A short questionnaire to measure wellbeing at work (Short-SWELL) and to examine the interaction between the employee and organisation. In: Charles, R. \& Wilkinson, J. eds. Contemporary Ergonomics and Human Factors 2017. Chartered Institute of Ergonomics and Human Factors. pp 200-205 (2017)

45. Smith, A.P.: Noise, performance efficiency and safety. International Archives of Occupational and Environmental Health, 62, 1 - 5 (1990)

46. Meyer, J.P., Allen, N.J.: A three component conceptualization of organizational commitment. Human Resource Management Review, 1(1), 61-89 (1991)

47. De Cooman, R., De Gieter, S., Pepermans, R., Jegers, M., Van Acker, F.: Development and validation of the work effort scale. European Journal of Psychological Assessment, 25(4), 266-273 (2009)

48. Kuvaas, B.: Performance appraisal satisfaction and employee outcomes: mediating and moderating roles of work motivation. The International Journal of Human Resource Management, 17(3), 504-522 (2006)

49. Smith, A.P.: Effects of noise on errors, injuries and subjective health of nursing staff. ICBEN 2017 (2017) 